\title{
POVIJESNI DISKURS STRUČNOG USAVRŠAVANJA I TRAJNE IZOBRAZBE NASTAVNIKA
}

\author{
Mirko Lukaš \\ Filozofski fakultet, Sveučilište Josipa Jurja \\ Strossmayera u Osijeku, Hrvatska \\ mlukas@ffos.hr
}

Primljeno: 11. 11. 2019.

\begin{abstract}
Usporednom analizom odabranih povijesnih i suvremenih pedagoških dokumenata stručno usavršavanje se prepoznaje kao trajna i neodvojiva komponenta nastavničke profesije. Trajno usavršavanje odgojnoobrazovnih djelatnika nepravedno se pripisuje tek vremenu paradigme cjeloživotnog obrazovanja. Pedagoški teoretičari nastavničkoj profesiji od njezinih početaka i pokušaja zakonske regulative te njezina društvenog etabliranja propisuju trajnu potrebu stručnog usavršavanja u svrhu profesionalnog razvitka i karijernog napredovanja, kao $i$ obvezu neprestanog učenja. Već u prvom zakonskom dokumentu iz 1874. godine propisano je individualno i produžno obrazovanje svih učitelja. Time stručno usavršavanje postaje ključna sastavnica učiteljske profesije, a kasnije i svih odgojno-obrazovnih djelatnika. Analizom povijesnih dokumenata utvrđena je sto pedeset godišnja zakonska $i$ propisima regulirana trajna obveza stručnog usavršavanja nastavnika koja u praksi često nije ostvarena. Nakon dosegnute sveučilišne razine inicijalnog obrazovanja svih nastavnika i učitelja, potrebno je stvoriti uvjete za njihovo sustavno i učinkovito stručno usavršavanje.
\end{abstract}

Ključne riječi: cjeloživotno obrazovanje, profesionalno učenje, permanentno obrazovanje, školski propisi

\section{Uvod*}

U raspravama o nastavničkom ${ }^{1}$ pozivu uvijek se ističe nastavnikova osobnost u kojoj bi trebale biti koncentrirane profesionalne kom-

* Ovaj rad financirala je Hrvatska zaklada za znanost projektom IP-2018-01-8363.

${ }^{1}$ Pojam nastavnik kao i pojam učitelj koristi se u ovom radu prema povijesnoj odrednici i vremenu unutar kojih se prikazuju. Čitateljima je dobro poznato da se na istoj viso- 
petencije, visoka svijest, zdrav afinitet prema djeci i mladima, životni optimizam i mnoge druge pozitivne karakterne osobine. Ni najbolje zamišljena reformska koncepcija, niti najbolje osmišljeni i sastavljeni nastavni planovi i programi neće se maknuti s početnih pozicija ako ih neće provoditi najkvalitetniji nastavnici. Bez nastavnika i njihove visoke motiviranosti i stručnog znanja sve bi ostalo samo na lijepim željama i velikim zamislima.

»Ali, nastavnici se ne rađaju gotovi, oni su kao i ostali građani rezultat određene razine razvijenosti društva i sredine, njihovih ekonomskih, političkih, kulturnih i pedagoških dostignuća i sistema obrazovanja (...) Oni u sebi nose sve vrline i mane svog vremena i društva.« (Leko, 1963, 185)

Nastavnički poziv ima niz gradbenih čimbenika. Nastavnik je prvenstveno odgojitelj koji u svom okruženju i društvu u cijelosti daje odgojnoj funkciji stvarni smisao, on ju osmišljava i uz svoje osobne i preuzete društvene ciljeve posreduje ih djeci i mladima. Prema definiranim nacionalnim ciljevima nastavnik se ne može postaviti administrativno i formalistički. On ih propituje, intimno u njih vjeruje i pridaje im objektivne vrijednosti. Ciljevi se na taj način oživotvore i postaju nastavnikova životna orijentacija, a on se trudi pronaći putove i modalitete kako ih što uspješnije realizirati u odgojno-obrazovnom procesu. Uspješan nastavnik to može jer je znanstveno poučen i prakseološki uvjeren u moći kao i u granice odgoja i obrazovanja.

Nastavnik je živa spona između onoga što se zbiva u školi i stvarnoga života. On svakodnevno unosi u školu i njezin kurikulum nove ideje i vrijednosti svog društva i vremena, on objašnjava pojave i nova znanstvena postignuća i u njega su usmjerene oči učenika. U ulozi odgojitelja nastavnici se dnevno susreću s nizom značajnih ljudskih problema: uspjesima i neuspjesima, željama i ambicijama, ravnodušnošću, velikim interesima i potpunom nezainteresiranošću, sukobima, razmimoilaženjima i tome slično. Navedene situacije traže od njih mnogo strpljenja, brige i razumijevanja, udubljivanja, empatičnost što ponekad potpuno prelazi mogućnosti jedne osobe koja uz navedeno ima i svoj osobni život. U procesu odgoja nastavnik ne prestaje biti čovjekom i

koškolskoj instituciji moglo u određenom povijesnom razdoblju dobiti zvanje nastavnika razredne nastave kao i prije ili nakon toga razdoblja zvanje učitelja. Prema povijesnom kontekstu kao i prema stupnju djelovanja pojedinih odgojno-obrazovnih djelatnika koriste se navedeni pojmovi koji su i službeno promovirani pojedinim zakonskim propisima u razdoblju u kojem se promatraju. 
ne može se pretvoriti u stroj koji sve objektivno i uspješno rješava. Kada bi on to i pokušavao radi određenog oportuniteta prema politici ili službenim stavovima ili radi izbjegavanja sukoba, tada bi prestao biti odgojitelj, prestao bi biti čovjekom.

Uz odgojiteljski poziv nastavniku se implicira i obrazovna funkcija kojom mlade uvodi u različita područja znanosti i života. U svom radu nastavnik je okrenut učeniku, njegovim interesima i kompetencijama. U svom radu on teži postupcima i metodama koji razvijaju osobnost učenika i njegovo stvaralaštvo jer samo takvim pristupom on ostvaruje najveće potencijale i vrijednosti.

Kako bi nastavnici bili u stanju sve to postići potrebno ih je uključiti u različite oblike stručnog usavršavanja.

"Stručno usavršavanje se definira kao aktivnosti čiji je cilj razvoj individualnih vještina, znanja, ekspertnosti i drugih značajki učitelja.« (OECD, 2014, 86)

Paechter (1996) pod stručnim usavršavanjem podrazumijeva aktivnost u kojoj sudionici sudjeluju individualno i u grupi kako bi unaprijedili svoju praksu, ali u isto vrijeme sačuvali svoju profesionalnu autonomiju. Pri tome se promovira »refleksivna kultura koja ohrabruje konstruktivnu, suradničku promjenu « (Paechter, 1996, 354). Stručno se usavršavanje danas najčešće organizira u različitim oblicima stručnih skupova, koji se mogu provoditi samo za pojedini predmet ili interdisciplinarno za više nastavnih predmeta, odnosno predmetnih područja. Stručni skupovi mogu biti organizirani na državnoj, regionalnoj ili županijskoj razini. Pažin Ilakovac i Skelac $(2010,13)$ navode kako se na stručnim skupovima »izmjenjuju predavanja, pedagoške radionice, iskustvene skupine, okrugli stolovi i sl., a sve češće su to videokonferencije i webni portali«. Osim toga stručni skupovi uključuju

»... raspravu, evaluaciju, evidenciju nazočnosti i potvrdnice o sudjelovanju. Stručno se usavršavanje povremeno odvija i uključivanjem učitelja i savjetnika u različite regionalne, državne ili međunarodne projekte.« (Pažin Ilakovac i Skelac, 2010, 13)

\section{Metodološki okvir istraživanja}

Predmet istraživanja je položaj stručnog usavršavanja nastavnika u Hrvatskoj od prvih školskih zakona do danas. Cilj je utvrditi obveznost 
stručnog usavršavanja nastavnika na temelju analize sadržaja odgovarajućih zakonskih propisa.

Za potrebe empirijskog istraživanja analizirani su slijedeći školski zakoni i pod zakonski akti:

- Druga obća hrvatska učiteljska skupština (1874)

- Pravilnik o napredovanju učitelja i nastavnika u osnovnom i srednjem školstvu (1995)

- Pravilnik o polaganju stručnog ispita učitelja i stručnih suradnika u osnovnom školstvu i nastavnika u srednjem školstvu (2003)

- Pravilnik o postupku, načinu i uvjetima ocjenjivanja i napredovanja nastavnika srednjih škola (1992)

- Propis o nastavi u pučkih učionah vojne Krajine. Zbirka zakonah i naredbah za vojnu Krajinu (1871)

- Školske naredbe, odluke, propisi, naputci, objavljeni u Službenom glasniku između 1883. i 1905. godine.

- Zakon od 14. listopada 1874. ob ustrojstvu pučkih škola i preparandija za pučko učiteljstvo u kraljevinah Hrvatskoj i Slavoniji

- Zakon od 31. listopada 1888. ob uređenju pučke nastave i obrazovanja pučkih učitelja u kraljevinah Hrvatskoj i Slavoniji

- Zakon o narodnim školama u Kraljevini Jugoslaviji od 5. 12. 1929.

- Zakon o stručnom usavršavanju nastavnika (1967)

- Zakon o usmjerenom obrazovanju (1991)

- Zakon o odgoju i obrazovanju u osnovnoj i srednjoj školi (2008)

- Zakon o odgoju i obrazovanju u osnovnoj i srednjoj školi (2018)

U radu je korištena povijesna analiza prethodno navedenih izvora u kojima se uspoređuju sadržaji prvih zakonskih propisa u svezi reguliranja djelovanja učiteljske profesije sa suvremenim propisima. Po svom karakteru ovo istraživanje je kvalitativno. U njemu se sadržaji dostupne pedagoške dokumentacije klasificiraju, analiziraju, opisuju i interpretiraju. U rezultatima istraživanja odgovara se na istraživačko pitanje u svezi postojanja propisane obveznosti u dostupnim zakonskim propisima članaka kojima se reguliraju oblici, trajanje i obveznost stručnog usavršavanja nastavnika. 


\section{Prilozi razvoju stručnog usavršavanja nastavnika}

Uvidom u literaturu s početka zakonske regulative odgoja i obrazovanja, točnije koncem 18. i tijekom 19. stoljeća na tadašnjim prostorima Hrvatske, saznaje se kako se prvo stručno usavršavanje učitelja provodilo putem školskih knjižnica i čitaonica, školskih časopisa te na učiteljskim sastancima i izvanrednim strukovnim tečajevima. Svaka pučka škola imala je obvezu otvoriti školsku knjižnicu u kojoj je učitelj skrbio o nabavci knjiga prema preporuci kraljevske zemaljske vlade. Osnivanje učiteljske knjižnice trebalo se provesti i u svakom kotaru pa je Pokrajinsko školsko vijeće okružnicom od 5. ožujka 1872. godine izdalo i naputak za reguliranje njihova rada Pravilnikom kotarskih knjižnica za učitelje. Uz otvaranje knjižnica koje su trebale poslužiti individualnom usavršavanju učitelja, oni su se mogli okupljati na županijskim i zemaljskim učiteljskim sastancima, odnosno njihovi stručni skupovi bili su organizirani na lokalnoj i državnoj razini (Kirin, 1909). U svakom se školskom kotaru barem jednom godišnje trebala održati učiteljska konferencija pod predsjedanjem kotarskog školskog nadzornika. Konferenciji su bili dužni sudjelovati svi učitelji javnih pučkih škola i učiteljskih zavoda. Na konferencijama su se učitelji dogovarali i raspravljali o stvarima koje su se odnosile na školstvo, govorilo se o učevnim strukama pučke škole, o načinu poučavanja, o nastavnim sredstvima, o uvođenju novih školskih knjiga i čitanki, o školskoj disciplini itd. Tečajevi za usavršavanje učitelja održavali su se u učiteljskim zavodima obično u vrijeme jesenskih praznika. Učitelji su se morali odazvati pozivu pokrajinskih školskih vlasti i dužni su bili doći na usavršavanje (Dizdar, 1913).

Usavršavanje nastavnika stručnih predmeta obavljalo se povremenim ferijalnim tečajevima koji su se financirali iz proračuna banovina. Tečajevi su se održavali u centrima banovina, a prema odobrenju bana (Glasnik stručne nastave, 21 i 22/1936). Tako je Naredbom Pokrajinske uprave za Hrvatsku i Slavoniju Odjeljenje za prosvjetu i vjeru od 20. svibnja 1922. godine odredilo da se u ljetnim praznicima 1922. godine održi u kr. Višoj pedagoškoj školi u Zagrebu stručno usavršavanje učitelja nižih pučkih škola za rad u šegrtskim školama. Tečaj je trajao šest tjedana, točnije od 3. srpnja do 12. kolovoza 1922. godine. Predviđeno je bilo poučavanje stručnih predmeta potrebnih učiteljima za rad u šegrtskoj školi. Tečaju je trebalo nazočiti četrdesetak učitelja iz Hrvatske i Slavonije, a prednost su imali učitelji koji su već prošli ospo- 
sobljavanje za rad u nižim pučkim školama i koji su radili u šegrtskoj školi. Sredstva za ovaj tečaj osiguravala je država, a stanovanje je bilo osigurano u internatu Obrtne škole u Zagrebu (Službeni glasnik, Komad IX/1922).

Sredinom 20. stoljeća mijenja se svrhovitost i tematika stručnog usavršavanja i pored organizacijskog sređivanja sustava školovanja i izgradnje mreže škola, pozornost državnih vlasti neposredno nakon Drugog svjetskog rata usmjerila se na načine kojima bi se podigla kvaliteta nastave i odgoja. Pedagoški standard toga vremena ovisio je o materijalnim uvjetima i broju učenika u razredu, ali u velikoj mjeri i o samim učiteljima i nastavnicima, o njihovoj stručnosti, pedagoškom znanju i zalaganju (Franković, 1958, 440).

U neposrednim godinama nakon oslobođenja učiteljski kadar nije bio dovoljno stručno osposobljen kako bi u potpunosti mogao udovoljiti nastavnom programu viših razreda sedmogodišnje škole. Nedostatak nastavnog osoblja primorao je Ministarstvo prosvjete na povećanje broja učiteljskih škola s tadašnjih 10 na 16, odnosno pažnja se usmjerila na povećanje broja učenika koji pohađaju ove škole. Prema statističkim podacima iz 1947. godine u tim se školama obrazovalo 4362 učenika ili $216 \%$ više u odnosu na prijeratno razdoblje. Iz podataka objavljenih u Pedagoškom radu iz 1947. godine, broj 2, jasno se može vidjeti povećanje postotka nastavnog kadra što ukazuje na pozitivnu politiku prema učiteljskim školama, ali ne i prema pedagoškom standardu u kojem još uvijek na jednog učitelja dolazi od 61 do 96 učenika ili u prosjeku 73 učenika. Osim povećanja broja učitelja ističe se važnost poučavanja novih nastavnika pomoću čitavog niza ponuđenih mjera uz redovito školovanje učitelja u učiteljskim školama. Najčešći oblici osposobljavanja bili su otvoreni tečajevi i popravni razredi koji su učiteljima omogućavali brže stručno osposobljavanje.

Nakon Rezolucije Informbiroa i raskida odnosa s tadašnjim SSSR-om jača utjecaj zapadne pedagogije što se osjeća i u Hrvatskoj pedesetih godina 20. stoljeća. Uz pomoć UNESCO više je istaknutih pedagoških djelatnika odlazilo na studijska putovanja u zapadne zemlje, a istodobno je stotinjak eksperata iz zapadne Europe i SAD boravilo kod nas. Među poznatijim ekspertima je 1957. godine na našim prostorima tri mjeseca boravio Dottrens, vodeći stručnjak na području individualizacije nastave provodeći ju uz pomoć nastavnih listića (Poljak, 1988). 
U cilju propitivanja i uvođenja pedagoških inovacija otvaraju se eksperimentalne škole. Prema odluci Savjeta za prosvjetu, nauku i kulturu NR Hrvatske od 13. listopada 1955. godine osnovano je osam eksperimentalnih škola i to dvije u Zagrebu te po jedna u Rijeci, Puli, Splitu, Starom Petrovom Selu, Borovu i Petrijanecu (Munjiza i Lukaš, 2006).

»Eksperimentalne škole bile su prvi znanstveno-istraživački centri poligoni u realizaciji i verifikaciji vanjske i unutarnje reforme naše osnovne škole.« (Poljak, 1988, 13)

Značajniji zadaci eksperimentalnih škola bili su: 1. praktična realizacija reformskih inovacija i njihova verifikacija; 2. radom i iskustvom djelovati na druge škole; 3. u suradnji sa Zavodom za unapređivanje osnovnog školstva SR Hrvatske raditi na studijskim istraživanjima; 4. javno objavljivati rezultate. Rezultati njihova rada bili su javno objavljivani od 1956. godine u Biltenu, a nakon toga u časopisu Pogledi $i$ iskustva. O svom radu Osnovna eksperimentalna škola Jordanovac, Zagreb (1964. godine) i Osnovna škola Nikola Tesla, Rijeka, su početkom 60-ih godina prošlog stoljeća tiskale monografije (Munjiza i Lukaš, 2006).

Sve to doprinijelo je razvoju pedagoške teorije i prakse. Međutim, i dalje je postojao problem stručne osposobljenosti učitelja. Naime, zbog povećanog industrijskog razvoja ${ }^{2}$ otvara se mogućnost zapošljavanja u industrijskom sektoru radi čega dio iskusnih učitelja napušta škole, a njihova mjesta popunjavaju mladi i manje iskusni učitelji što se odražavalo i na kvalitetu rada škola. Uvidjevši nedostatke, Ministarstvo prosvjete pristupilo je stručnom ali i idejnom usavršavanju nastavnika jer se smatralo da bez toga nije moguće podići kvalitetu nastave u školama. Zbog toga je u Zakonu o stručnom usavršavanju nastavnika (NN, 27/1967; Prosvjetni vjesnik, 7-8/1967) navedeno da nastavnici imaju obvezu stručno i pedagoški se usavršavati sukladno zahtjevima suvremenog odgoja i obrazovanja. Stručna usavršavanja provodila su se prema navedenom propisu unutar škola u kojima su nastavnici bili zaposleni, u školama za obrazovanje nastavnika, zavodima za unaprjeđivanje osnovnog i stručnog obrazovanja, stručnim udrugama te u drugim organizacijama.

${ }^{2}$ Kao rezultat gospodarskog rasta kupovna je »moć stanovništva u razdoblju 1950.1980. godine porasla četiri puta.« (Puljiz, 2008, 26) 


\section{Stručni ispiti kao poticajni čimbenik daljnjem usavršavanju}

S obzirom na veliki broj manje iskusnih nastavnika, 60 -ih godina prošlog stoljeća posvećuje se posebna pozornost njihovom stručnom usavršavanju. Najčešći oblici stručnog usavršavanja u to vrijeme bili su stažiranje, uvodni pedagoški seminar, praćenje nastavničkog rada i stručno-metodički seminar ili stručne konzultacije. Nastavnici koji su započeli svoj rad u školama od 1. rujna 1969. godine morali su polagati stručni ispit prema novim odredbama. Za ove nastavnike izrađeni su posebni programi stručnog usavršavanja, a objavljeni su u Prosvjetnom vjesniku br. 6 od 1969. godine. Nastavnik početnik pohađanjem dogovorenih oblika stručnog usavršavanja morao se pripremati za polaganje stručnog ispita. Poslije završenih posebnih oblika stručnog usavršavanja i dvije godine radnog iskustva u nastavi, nastavnici su polagali stručni ispit kojim se provjeravala primjena stručnog znanja u nastavnom radu, poznavanje i primjena osnovnih psiholoških i pedagoških zakonitosti u nastavi i poznavanje društveno-ekonomskih odnosa, odgojno-obrazovnog sustava te rad u školi.

Novim Zakonom o stručnom usavršavanju nastavnika i Pravilnikom o polaganju stručnih ispita i oblicima stručnog usavršavanja nastavnika prema novom sustavu od lipnja 1969. godine uvedene su i određene osobitosti. Nastavniku početniku ovo je bila prva titula koju je dobio kao mlada osoba koja se zaposlila u školi, a svoje nove spoznaje o individualnim samostalnim oblicima rada trebala je povezati $\mathrm{s}$ tadašnjim kolektivnim oblicima rada u školama. Stoga je sustav stručnog usavršavanja bio osmišljen za provođenje putem dva samostalna ciklusa: prvi je ciklus obuhvaćao nastavnički staž, uvodni pedagoški seminar, praktični odgojno-obrazovni (nastavni) rad, stručno-pedagoški seminar ili stručne konzultacije i stručni ispit. Sve navedeno bilo je namijenjeno osobama do navršenih 5 godina radnog staža, dok je drugi ciklus bio namijenjen svim ostalim nastavnicima. Ovakav oblik početnog stručnog usavršavanja nastavnika zadržao se s povremenim prekidima sve do današnjih dana u različitim oblicima realizacije i vremenskom trajanju. 


\section{Administrativno regulirano usavršavanje trajnom izobrazbom}

U razvoju školskog sustava početna je nastavnička djelatnost bila formalno i institucionalno potpuno nedefinirana pa su ovu funkciju obnašale osobe različitih iskustava, izobrazbe i sposobnosti ali i osobnih kvaliteta. U početku je unutar ovoga sustava često dolazilo do velikih prijepora i pojave upotreba nedozvoljenih naročito disciplinskih postupaka kako prema djeci tako i prema pojedinim učiteljima. Uređenjem funkcioniranja države dolazilo je i do uređenja njenih podsustava, a jedan od njih je i obrazovanje. Predstavnici vlasti započeli su prepoznavati vrijednosti odgojno-obrazovnih aktivnosti pa su ovu djelatnost uredili zakonski kako u kompetencijskim zahtjevima tako i u postupcima potrebnima za njezino uspješno provođenje. U rasponu od više od sto pedeset godina vidljivo je da funkcija stručnog i profesionalnog usavršavanja učitelja nikada nije bila dovedena u pitanje. Već u prvom zakonskom propisu ona je bila određena pojmom obvezatna ili »svi su učitelji (...) dužni doći«. Čitajući suvremenu literaturu u pojedinim se tekstovima pronalaze tvrdnje kako je usavršavanje nastavnika »odnedavno« postalo obvezno (Milović, 2010), što nije točno.

Radi što kvalitetnije nastavničke osposobljenosti u sustavu koji se mijenja pod utjecajem društvenih promjena, bilo je potrebno uvesti produžno, permanentno ili cjeloživotno obrazovanje. Tako da se o stručnom usavršavanju ne govori kao o odvojenom sustavu osposobljavanja nastavnika, već kao o trajnoj obvezi proizašloj iz same profesije i njezinog opisa posla i djelovanja.

Početnim se zakonima propisuju obvezni i točno određeni oblici provođenja stručnog usavršavanja, dok se suvremenim propisima ostavljaju mogućnosti za artikuliranje i osmišljavanje sasvim novih strategija i scenarija provedbe ovoga procesa, jer se njime osposobljavaju sudionici upravo za nepredvidivu i promjenjivu budućnost, iz današnje perspektive moguće potpuno nepoznatu.

Prvim školskim zakonom Zakon ob ustroju pučkih škola i preparandija za pučko učiteljstvo u kraljevinah Hrvatskoj i Slavoniji od 14. listopada 1874. godine na prostoru tadašnje Hrvatske, Glavom pet reguliralo se stručno usavršavanje učitelja sljedećim paragrafima (člancima): 
»Glava peta, O produžnom obrazovanju učitelja: § 94. Da se učitelji mogu u znanstvenom i pedagoškom pravcu i dalje obrazivati, zato služe knjižnice, školski časopis, učiteljski sastanci i izvanredni produžni učevni tečaji. § 95. Svaka je školska obćina dužna davati najmanje $10 \mathrm{fr}$. na godinu, da se utemelji i uzdržava obćinska knjižnica, kojom upravlja dotični učitelj ili učiteljski zbor. § 96. U području svakog kotarskog suda mora se najmanje jedan put na godinu pod predsjedom županijsko-školskoga nadzornika držati učiteljski sastanak. § 97. Svi su učitelji javnih pučkih školah dotičnoga kotarskoga suda i u obsegu istoga nalazećih se možda preparandijah dužni doći na učiteljski sastanak, a učiteljem privatnih pučkih škola prosto je doći na taj sastanak. Učiteljem javnih pučkih školah, polazećim na učiteljski sastanak, dužne su dotične školske obćine dati u tu svrhu potrebitu pripomoć. § 98. Zemaljska vlada može, kada za potrebno obnadje, sazvati sastanak učitelja iz sve zemlje. § 99. Učiteljski sastanci pretresaju didaktičko-pedagogička, disciplinarna i materijalna pitanja tičuća se pučkih školah. § 100. Na svakoj se preparandiji prema potrebi u vrieme jesenskih praznika drže izvanredni produžni učevni tečaji. § 101. Svi su javi učitelji obćih pučkih školah, koje pozove zemaljska vlada, dužni doći na produžni učevni tečaj, i to o svom trošku.«

U narednom, drugom školskom zakonu Zakon ob uredjenju pučke nastave i obrazovanja pučkih učitelja u kraljevinah Hrvatskoj i Slavoniji od 31. listopada 1888. godine s hrvatskih prostora, možemo pročitati istovjetne odredbe zakonskih propisa, regulirane istom Glavom, uz vrlo male izmjene. Kompariramo li prve administrativne odredbe sa stogodišnjim odmakom uvidjet ćemo sličnu zakonsku regulativu izrečenu suvremenim hrvatskim jezikom. Napredovanja učitelja i nastavnika u suvremenoj Hrvatskoj regulirana su pravnim aktima pod nazivom Pravilnik o utvrđivanju zvanja učitelja i stručnih suradnika u osnovnim školama te postupku, načinu i uvjetima njihova stjecanja (NN, 59/90. i 27/93.) i Pravilnik o postupku, načinu i uvjetima ocjenjivanja i napredovanja nastavnika srednjih škola i učeničkih domova (NN, 19/92., 26/93., 27/93. i 11/94.). Ovim se propisima uređuje napredovanje nastavnika, koje je moguće samo u slučaju kada oni zadovolje uvjete stručnog usavršavanja:

»Elementi vrednovanja stručnog usavršavanja učitelja odnosno nastavnika su: - sudjelovanje u stručnom usavršavanju što ga ustrojava Ministarstvo prosvjete i športa, - sudjelovanje u stručnom usavršavanju koje provode stručne ustanove i udruge, - stručno usavršavanje praćenjem suvremene stručne literature i časopisa što se utvrđuje iskazom učitelja odnosno nastavnika i popisom bibliografskih jedinica. Stručno usavršavanje vrednuje se kao: - redovito (za redovito sudjelovanje u radu stručnih skupova koje ustrojava Ministarstvo prosvjete i športa te sustavno praćenje stručne literature i časopisa), - povremeno (za povremene izostanke, vlastitim propustom, sa stručnog usa- 
vršavanja koje ustrojava Ministarstvo prosvjete i športa i neredovito praćenje suvremene stručne literature), - izostaje (za stalno izostajanje, vlastitim propustom, sa stručnog usavršavanja koje ustrojava Ministarstvo prosvjete i športa i ne praćenje suvremene stručne literature).«(NN, 86/1995)

Navedeni pravilnici 1995. godine objedinjeni su u jedan zajednički Pravilnik o napredovanju učitelja i nastavnika u osnovnom i srednjem školstvu koji je regulirao kako su učitelji i stručni suradnici dužni permanentno se usavršavati. Pod permanentnim usavršavanjem podrazumijeva se usavršavanje u struci i usavršavanje za stručno-metodički, pedagoški i andragoški rad. Program i organizaciju permanentnog usavršavanja utvrđuje i provodi Zavod za školstvo (NN, 62/03).

Na temelju članka 10. Zakona o osnovnom školstvu Hrvatski sabor je na sjednici 16. svibnja 2008. godine donio Državni pedagoški standard osnovnoškolskog sustava odgoja i obrazovanja kojim se definira pojam stručnog usavršavanja učitelja i stručnih suradnika kao

»... trajni stručni razvoj učitelja i stručnih suradnika kroz službene i neslužbene, skupne ili pojedinačne oblike obrazovanja i stjecanja dodatnih znanja i vještina s ciljem unapređenja osobnih sposobnosti i vještina iz svoje struke i sveukupnoga odgojno-obrazovnog rada.« (NN, 63/2008)

Točkom VIII. u ovom propisu određuju se mjerila za trajno profesionalno usavršavanje, napredovanje ravnatelja, učitelja i stručnih suradnika te mjerila za osposobljavanje i stručno usavršavanje ostalih radnika:

»Članak 18::

(1) Ravnatelji, učitelji i stručni suradnici imaju obvezu trajnoga profesionalnog usavršavanja: - najmanje jednom u dvije godine sudjelovati na profesionalnom usavršavanju na državnoj razini, - najmanje tri puta godišnje sudjelovati na profesionalnom usavršavanju na županijskoj razini, - redovito sudjelovati na profesionalnim usavršavanjima u školi u kojoj rade, - osobno se profesionalno usavršavati u skladu s poslovima i obvezama za koje su zaduženi.

(2) Sadržaje obveznoga profesionalnog usavršavanja odobrava ministarstvo nadležno za obrazovanje sukladno nacionalnoj strategiji odgojno-obrazovnog sustava, a organiziraju ih i provode: nadležne ustanove za odgoj i obrazovanje, i drugi subjekti koji za to imaju odobrenje ministarstva nadležnog za obrazovanje.

(3) Programe profesionalnog usavršavanja na državnoj i županijskoj razini za sljedeću školsku godinu objavljuje ministarstvo nadležno za obrazovanje najkasnije do kraja tekuće nastavne godine. 
(4) Učiteljsko vijeće godišnje usvaja plan trajnoga profesionalnog usavršavanja i on postaje obveza za sve odgojno-obrazovne radnike.

(5) Godišnji plan i program stručnog usavršavanja učitelja i stručnog suradnika sastavni je dio godišnjega plana i programa rada škole.

(6) U godišnjemu planu i programu stručnog usavršavanja za svakog učitelja i stručnog suradnika navedeni su oblici stručnog usavršavanja i predviđeni broj sati po pojedinom obliku.

(7) Svaki učitelj i stručni suradnik dužan je barem jednom godišnje podnijeti izvješće o svome profesionalnom usavršavanju.

(8) Sudionicima trajnoga profesionalnog usavršavanja na državnoj i županijskoj razini izdaje se potvrda o stručnome usavršavanju. Sudjelovanje na stručnim usavršavanjima učitelja i stručnih suradnika vrednuje se prema provedbenim propisima nadležnog ministarstva.« (NN, 63/2008)

U navedenim komponentama standarda vrlo se jasno ističu trajnost stručnog usavršavanja svih djelatnika u odgoju i obrazovanju. Zatim se definiraju i točno određuju vremenski intervali u kojima se mora djelovati na realizaciji aktivnosti usavršavanja. Propisom standarda određene su instance koje odobravaju načine i sadržaje provođenja ovih aktivnosti. Zatim se odobravaju nositelji ili subjekti koji rade na konkretnim osmišljavanjima i provedbi navedenih aktivnosti i odobrenim programima.

Ono što se nedovoljno prepoznaje u današnjoj praksi odgojnoobrazovnog sustava je obveza izrade godišnjeg plana i programa osobnog usavršavanja. Svaki sudionik odgojno-obrazovnog procesa s pozicije autoriteta planira broj sati godišnje provedenih na usavršavanju kao i poželjne oblike kojima će prema osobnom izboru provesti svoje usavršavanje. Sve navedeno ima obvezu postati sastavnim dijelom i u današnjem kurikulumu poželjna komponenta dostupna evaluacijama i vanjskim i unutarnjim vrednovanjima.

Zakonom o odgoju i obrazovanju u osnovnoj i srednjoj školi iz 2008. godine određuje se glavom XII. stručno osposobljavanje, usavršavanje, napredovanje i izdavanje licencija:

»Članak 115.:

(1) Učitelji, nastavnici, stručni suradnici i ravnatelji školske ustanove imaju pravo i obvezu trajno se stručno osposobljavati i usavršavati kroz programe koje je odobrilo Ministarstvo.

(2) Pod stalnim stručnim osposobljavanjem i usavršavanjem iz stavka 1. ovog članka podrazumijeva se pojedinačno i organizirano usavršavanje u matičnoj znanosti u području pedagogije, didaktike, obrazovne psihologi- 
je, metodike, informacijsko-komunikacijskih tehnologija, savjetodavnog rada, upravljanja, obrazovnih politika i drugih područja relevantnih za učinkovito i visokokvalitetno obavljanje odgojno-obrazovne djelatnosti u školskim ustanovama.

(3) Programe stručnog osposobljavanja i usavršavanja iz stavka 1. ovog članka organiziraju i provode ustanove nadležne za stručno usavršavanje.

(4) Uz ustanove iz stavka 3. ovog članka programe iz stavka 1. ovog članka mogu provoditi i visoka učilišta te subjekti iz civilnog sektora.

(5) Ustanove iz stavka 3. i 4. ovog članka programe stručnog osposobljavanja i usavršavanja mogu izvoditi i u školskim ustanovama.

(6) Program stručnog osposobljavanja i usavršavanja treba sadržavati temu, namjenu, ciljeve programa iskazane kompetencijama, metode poučavanja, organizaciju, način vrednovanja i oblik certificiranja, broj polaznika, vrijeme trajanja programa i troškovnik.

(7) Način i postupak stručnog osposobljavanja i usavršavanja učitelja, nastavnika, stručnih suradnika i ravnatelja propisuje ministar.« (NN, 87/2008)

Iste obveze prenesene su i zakonski propisane i u Zakonu o odgoju i obrazovanju u osnovnoj i srednjoj školi 2017-2018 (NN68/18). U posljednjih tridesetak godina hrvatskog školstva nije se dogodilo ništa značajno što se prethodnim propisima učiteljske profesije nije već zabilježilo. Stoga se i u suvremenim prijedlozima Strategije ukazuje na potrebu unaprjeđenja stručnog usavršavanja prosvjetnih djelatnika:

»Postoje različiti oblici, velik broj programa i tema za različite ciljne skupine u zemlji i inozemstvu, no ta usavršavanja nisu usklađena, planiraju se nezavisno i ne omogućuju ujednačavanje kompetencija učitelja različitih profila. Stručno usavršavanje koje organiziraju za to nadležne agencije besplatno je, informacije su javno dostupne i jednostavno se prijaviti, ali ono je uglavnom jednokratno, ne nudi dovoljno iskustvenog učenja i refleksije te nedostaje praćenje i podrška u primjeni.«(MZOS, 2014, 81)

\section{Povijesni pregled razvitka oblika stručnog usavršavanja}

U početku razvoja stručnog usavršavanja učitelja ono je označeno terminom produžno obrazovanje. Zadaće ovog oblika pomoći učiteljima proizlazile su iz osobno iskazanih potreba samih učitelja kako i od državnih vlasti prepoznatih potreba za usuglašavanjem i ujednačavanjem rada svih učitelja. U početku su se učitelji samoinicijativno okupljali u određenim školama kako bi razmjenjivali svoja iskustva i na taj način poboljšavali ili u potpunosti mijenjali dotadašnji način rada. 
Zatim se Zakonom iz 1874. godine obvezuju kotarske, okružne i zemaljske vlasti organizirati učiteljske sastanke i skupštine. Problematika koja je u početku zaokupljala učitelje na ovim susretima odnosila se na razgovore i savjetovanja o nastavnim predmetima, učevnim metodama, pomagalima, uvođenju nove literature i školskoj disciplini (Martinović, 1912, 409).

Analizom sadržaja dostupnih zakona iz 1871., 1874., 1888. i 1929. godine u svakom se od njih nalazi poglavlje o produžnom obrazovanju učitelja. Iz navedenih se sadržaja zaključuje kako se ono realizira na teritorijalnom principu, barem jedan puta godišnje. Oblici realizacije najčešće su bili susreti i savjetovanja učitelja ili individualno usavršavanje putem školskih časopisa, pedagoške literature ili u školskim knjižnicama. Ono što dominira svakim od ovih navedenih propisa je obveznost nazočnosti organiziranim okupljanjima, točnije skupštinama svih učitelja javnih škola, dok se isto preporučuje i učiteljima privatnih škola. Troškove dolaska na susrete u početku su učitelji ipak sami snosili iz svog privatnog budžeta, a kasnije ih je u tome započela podupirati i sama država.

Uz obvezne skupštine bilo je tijekom godine moguće organizirati i povremene produžne tečajeve. Oni su se organizirali tijekom ljetnih praznika u trajanju od najmanje jednog mjeseca. Učitelji su na ovim susretima mogli dobiti spoznaje o novim nastavnim planovima i programima, novim tehnikama rada, informacije o primjeni novih vještina rada kao i o potrebi promjene pojedinih zastarjelih metoda rada. Za ilustraciju možemo navesti izabrane primjere tečajeva: 1886. godine proveden je tečaj cijepljenja američke loze, 1893. godine tečaj o primjeni slöjda ${ }^{3}$ i 1913. godine risarski tečaj (Munjiza i Lukaš, 2007).

Analizom sadržaja dostupne povijesne pedagoške dokumentacije i literature vidljivo je kako su početni pristupi stručnog usavršavanja istovjetni pristupima koji se i danas preporučuju u suvremenoj zakonskoj legislativi i u njoj se i nadalje propisuju kao obvezni. Međutim, u suvremenoj praksi stručnog usavršavanja postoji diskrepancija između proklamirane obveznosti i praktične realizacije. Naime, danas stručno

${ }^{3}$ Riječ sloyd potječe od švedske riječi Slöjd, što u prijevodu znači zanat ili ručni rad. Prije svega se odnosi na drvene proizvode ali i navijanje papira i šivanje, vezenje, pletenje i kukičanje. Sloyd je imao zapažen utjecaj na rani razvoj ručnog treninga, ručne umjetnosti, industrijskog obrazovanja i tehničkog obrazovanja (Rich, 1905). 
usavršavanje često ovisi o interesu ili motivaciji svakoga od učitelja pojedinačno.

Uz navedene povremene tečajeve, učitelji su u prošlosti pohađali i dodatna obrazovanja na stranim sveučilištima. Za naše stručno-pedagoško područje vrlo je značajno bilo pohađanje Bečkog pedagogiuma. Uz pohađanje nastave na inozemnim visokim školama, bilo je moguće pohađati i studijska specijalistička usavršavanja. Navedeni su oblici prepoznati i mogu se usporediti s današnjim razmjenama ili gostovanjima učenika, studenata ili nastavnika prakticiranima u obliku putovanja, posjeta i boravaka na stranim odgojno-obrazovnim institucijama. Tu praksu ilustrira sljedeći Filipovićev tekst:

\begin{abstract}
»Bivši o zemaljskom trošku na XIX. obćoj njemačkoj učiteljskoj skupštini, koja se ove godine 8., 9. i 10. lipnja u Beču držala, gledao sam, da se što više tom sgodom u prilog našega napredka koristim. S tog sam polazio ne samo sjednice rečene skupštine, nego sam obišao i pregledao također njekoje učevne zavode, spadajuće u krug pučke škole; pa što sam vidio, čuo i izkusio, to evo priobćujem u ovo njekoliko slika svojim sudrugovom i prijateljem pučke škole i obrazovanosti. U koliko je uobće za misaona čovjeka zanimivo i poučno, da sazna idee, koje drugdje s narodnim napredkom pokreću, u toliko se nadam, da će i ove moje slike barem gdjekojemu dobro doći; a to tim više, počem se i u nas o napredku obrazovanosti snuje i radi, i počem nam kao zaostalim druga i nije, nego se u naprednije ugledati, pa što u njih dobra nađemo, to u svoj cvjetnjak da presadjujemo.«(Filipović, 1870, 1)
\end{abstract}

Važnu ulogu u popularizaciji i poticanju obveznosti stručnog usavršavanja učiteljima pružale su i (stručne) staleške udruge. Tako je 1874. godine nakon Druge opće hrvatske učiteljske skupštine u Petrinji započelo osnivanje i otvaranje kotarskih učiteljskih društava. Navodi se da ih je potkraj 19. stoljeća već bilo 37 (Napredak, 1903 /39/, 621). Kotarskim učiteljskim društvima učitelji samostalno artikuliraju i realiziraju produžno obrazovanje, ali istodobno i druge zahtjeve, poput onih o društveno-materijalnom položaju tadašnjih učitelja (Munjiza, 2005). Izrazito važnu ulogu na području produžnog obrazovanja učitelja od svog utemeljenja 1871. godine do danas ima i Hrvatsko pedagogijskoknjiževni zbor (Vrgoč, 2007).

Svojevremeno su stvarani i centri za usavršavanje nastavnika (Pionirsko naselje Zagreb), vođene su diskusije da se nastavničke škole objedine i pretvore u centre za obrazovanje i usavršavanje nastavnika, potom je zadatak usavršavanja prenijet na prosvjetno-pedagoške zavode i prosvjetne savjetnike. U tom vremenu držao se velik broj stručnih 
skupova za nastavnike, koji nisu davali nikakve formalne kvalifikacije (Potkonjak, 1981).

Može se zaključiti da je u našem odgojno-obrazovnom sustavu uvijek bilo mnogo pozitivnih ideja i zamisli koje su povremeno doprinosile kvalitetnim pomacima. Ali treba istaknuti da su isto tako mnoge dobre ideje vrlo brzo napuštane i uvodilo se nešto »novo«.

$»$ Sve je to izraz i posljedica odsustva jedne određenije koncepcije o problemu obrazovanja i usavršavanja nastavnika. Zato je neophodno tražiti rješenja koja će u našim uvjetima najuspješnije omogućiti stvaranje jedinstvenog sustava obrazovanja i usavršavanja nastavnika svih kategorija.« (Potkonjak, 1981, 67)

Analizom povijesnih dokumenata utvrdili smo kontinuitet iskazivanja potpore većoj aktivnosti svakog pojedinca. Uz početne pasivno-sudjelujuće oblike tražili su se i novi aktivniji oblici sudjelovanja u profesionalnom usavršavanju koji se danas prepoznaju u pedagoškim radionicama, timskim projektima, akcijskim istraživanjima, online obrazovanju itd. (Munjiza i Lukaš, 2007, 460).

Nikada nisu prestali biti popularni i individualni oblici usavršavanja čitanjem dostupne literature. Na primjer, danas je poznata i vrlo popularna Sahlbergova knjiga Lekcije iz Finske (2012) o promjeni finskog odgojno-obrazovnog sustava koja pruža nadu svima onima koji su zabrinuti za mogućnost mijenjanja odgojno-obrazovnog sustava. Navedena, kao i mnoge druge knjige koje se svakodnevno tiskaju, postaju dostupne učiteljima na svim razinama koji se pomoću njih mogu stručno informirati. Dostupnosti stručne literature pridonosi internet na kojemu je moguće pronaći brojne radove objavljene u zemlji i inozemstvu.

Od nastavnika se danas traži posjedovanje više znanja o svojem predmetu, umijeće poticanja i vođenja procesa učenja na višim razinama mišljenja, sposobnost suradnje u multidisciplinarnim timovima, aktivnije sudjelovanje u odlučivanju u školi, visoko razvijene komunikacijske vještine te sposobnost djelovanja u okruženju koje je podložno stalnim promjenama. U isto se vrijeme od nastavnika očekuje da su u stanju prilagoditi se različitim stilovima učenja učenika, međusobno poštovanje te multikulturalna tolerancija i stvaranje poticajnog okruženja za učenje, poštujući obrazovne standarde i potičući visoka akademska postignuća svojih učenika (Delennoy, 2000). Kako bi sve to bilo moguće postići, potrebno je osigurati mirno, motivirajuće i opuštajuće ozračje na stručnim skupovima nastavnika: 
»Stil poučavanja ovisi o onome što nam je osobno ugodno, nećemo koristiti u razredu aktivnosti za koje osjećamo da prijete i ugrožavaju naš osobni identitet. Znanstveni aspekt svakog predmeta ne smije ugroziti duhovnu i moralnu vrijednost predmeta, ali i sudionika nastavnog procesa. Proces poučavanja okrenut upoznavanju učenika i nastavnika kao osoba s duhovnim, moralnim i emocionalnim vrijednostima podignut će motivaciju za proces učenja i spriječiti konfliktno ponašanje sudionika samog procesa. Ukoliko ovakav red vrijednosti nastavnici osobno iskustveno dožive tijekom stručnog skupa od strane svih predavača, bez obzira jesu li znanstvenici, praktičari ili savjetnici, prenijet će ga i u razred.«(Ambruš-Kiš, 2010, 68)

\section{Zaključno}

Svaki nastavnik cijeli život uči kako bi mogao s uspjehom pratiti dostignuća u svojoj struci, spoznaje iz pedagogije, psihologije i ostalih znanstvenih područja. Kako je ovakav stav u cijelom svijetu prihvaćen, već odavana se pristupilo izgradnji raznolikih oblika usavršavanja kojima se pridaje istovjetna pozornost koliko i obrazovanju budućih nastavnika. Stoga se paralelno s promjenama i porastom godina studija za stjecanje nastavnih kompetencija na visokim učilištima i napretkom koji se odvija na području nastavnog osposobljavanja, osmišljavaju i stvaraju nove strategije za daljnje usavršavanje nastavnika.

Redovitim obrazovanjem gotovo je nemoguće steći potpuno obrazovanje i postati osposobljenim za obavljanje svih aktivnosti unutar cjelokupnog radnog vijeka nastavnika. Promjene u pojedinim znanostima kao i stalne promjene u društvenim procesima zahtijevaju trajno uvođenje novina u nastavne programe na svim razinama obrazovanja što podrazumijeva trajno osposobljavanje nastavnika. Nove spoznaje koje se pojavljuju u psihološkoj, pedagoškoj i metodičkim znanostima moraju postati dostupne i s njima se moraju upoznati svi sudionici odgojno-obrazovnog procesa kako bi mogli unaprjeđivati i povećavati njegovu kvalitetu. Nastavnički poziv i vođenje nastave podrazumijeva pozitivan odnos prema usavršavanju u društvu stalnih promjena.

Završetkom temeljnog obrazovanja koje se danas odvija na visokoškolskoj razini kao i stjecanjem potrebnih kvalifikacija za rad u sustavu odgoja i obrazovanja, svim funkcijama koje su u njemu obuhvaćene zakonskim se propisima reguliraju prava i obveze. Tako se raznim zakonskim propisima, pravilnicima, dopunskim i podzakonskim aktima propisuju kako obveze u neposrednom odgojno-obrazovnom radu 
tako i ostale obveze koje se od odgojno-obrazovnih djelatnika očekuju. Temeljni zakonski propisi određuju koliko će odgojno-obrazovni djelatnici provesti sati tjedno neposredno radeći s učenicima, kao i koliko im preostaje vremena posvetiti se poslovima koje obavljaju u sklopu preostalog radnog vremena. Ostali poslovi obično su zakonski opisani kao planiranje, programiranje, praćenje i vrednovanje učenika, zatim suradnja sa svim ostalim čimbenicima odgojno-obrazovnog procesa, savjetodavni rad te poslovi stručnog usavršavanja.

Analizirajući zakonske propise uopće nije potrebno govoriti o mogućnosti, već o obvezi provedbe navedenih aktivnosti jer su one zakonski propisane za sve djelatnike u sustavu odgoja i obrazovanja. Međutim, iskustva nam ponekad govore sasvim suprotno i u praksi se nailazi na različite pristupe obvezi stručnog usavršavanja.

Na samom početku svoje radne karijere nastavnici početnici obogaćivali su svoje teorijske spoznaje putem pripravničkog staža i polaganjem stručnog državnog ispita. Ovako započeto stručno usavršavanje nastavljalo se tijekom radnog vijeka putem raznovrsnih oblika individualnih ili skupnih susreta zaposlenika u odgoju i obrazovanju. Najčešći individualni oblici stručnog usavršavanja realizirali su se čitanjem odgovarajuće stručne literature, dok su se skupni oblici provodili putem seminara, sudjelovanjima na skupovima, savjetovanjima, kongresima i simpozijima te okruglim stolovima o određenim stručnim temama.

Ovim se radom nastoji poslati poruka o važnosti brige oko sustavne realizacije različitih oblika stručnog usavršavanja koji će biti dostupni svim učiteljima. Omogućavanjem sustavnih oblika osposobljavanja sudionika odgojno-obrazovnih procesa odgovorit će se na zakonsku obvezu trajne brige o napredovanju i pripremi učitelja i nastavnika za uspješan profesionalni razvoj. Ovakvim načinom može se krenuti u unapređenje odgojno-obrazovnog sustava koje se treba temeljiti na kvalitetno vođenom sustavu profesionalnog učenja i razvoja nastavnika. Promjene su poželjne samo onda kada ih oni koji su zaduženi za njihovu implementaciju razumiju i znadu se njima koristiti. 


\section{Literatura}

Ambruš-Kiš, Ružica (2010), »Načela učinkovitog usavršavanja usmjerenog prema profesionalnom razvoju «, u: Milović, Sanja (ur.), Stručno usavršavanje i profesionalni razvoj: Zbornik radova, Zagreb: Agencija za odgoj i obrazovanje, str. 65-70.

Barbaroša-Šikić, Mirela (2010), »Izazovi u osmišljavanju i upravljanju programima usavršavanja«, u: Milović, Sanja (ur.), Stručno usavršavanje i profesionalni razvoj: Zbornik radova, Zagreb: Agencija za odgoj i obrazovanje, str. 15-20.

Dizdar, Ilija (2013), Zakoni i propisi za opće pučke i za građanske škole u Dalmaciji, Dubrovnik: Štamparija De Giulli i drug u Dubrovniku.

Filipović, Ivan (1870), Bečke slike, Zagreb: Tisak Lav. Hartmana i družbe.

Franković, Dragutin (1958), Povijest školstva i pedagogije u Hrvatskoj, Zagreb: PKZ.

Glasnik stručne nastave (1936), Uredba o organizaciji, nastavnom planu, stručnoj spremi nastavnika i upotrebi udžbenika u stručnim produžnim školama, 21-22/1936.

[MZOS] Ministarstvo znanosti, obrazovanja i sporta (2014), Nove boje znanja: Strategija obrazovanja, znanosti i tehnologije, Zagreb: Ministarstvo znanosti, obrazovanja i sporta RH.

Kirin, Josip (1909), Uređenje pučke nastave u kraljevinama Hrvatskoj i Slavoniji s naputkom o školskoj administraciji, 2. izdanje, Zagreb: Tisak i naklada knjižare L. Hartmana.

Klobučar, Dragutin (1902). »Školske knjižnice«, Napredak, 46(32), str. 506-507.

Leko, Ivan (1963), Novi školski sistem, Sarajevo: Zavod za izdavanje udžbenika.

Martinović, Ivan (1906), »Priprava za učiteljsko zvanje u osamnaestom stoljeću «, Napredak, 47(4), str. 59-61.

Martinović, Ivan (1912), Povijesne crtice o školstvu brodske pukovnije i brodskog okružja, Zagreb: Pišćeva naklada.

Milović, Sanja (2010), »Stručno usavršavanje i profesionalni razvoj«, u: Milović, Sanja (ur.), Stručno usavršavanje i profesionalni razvoj: Zbornik radova, Zagreb: Agencija za odgoj i obrazovanje, str. 27-34.

Munjiza, Emerik i Peko, Anđelka (2005), »Uloga kotarskih učiteljskih društava u permanentnom usavršavanju učitelja«, u: Tataković, Nevenka (ur.), Integrativna komunikacija u nastavi i odgojnim aktivnostima, Pula: Visoka učiteljska škola, str. 365-377.

Munjiza, Emerik i Lukaš, Mirko (2006), »Pedagoško-psihološko osposobljavanje učitelja u visokoškolskim ustanovama«, Odgojne znanosti, 8(2), str. 361-383. 
Munjiza, Emerik i Lukaš, Mirko (2007), »Cjeloživotno obrazovanje učitelja između prošlosti i sadašnjosti s pogledom na budućnost«, u: Previšić, Vlatko; Šoljan, Nikša Nikola; Hrvatić, Neven (ur.), Pedagogija prema cjeloživotnom obrazovanju $i$ društvu znanja, svezak 2, Zagreb: Hrvatsko Pedagogijsko Društvo, str. 456-464.

[NN] Narodne novine (1992), Zakon o usmjerenom obrazovanju, 11/1991 (27. 7. 2018.).

[NN] Narodne novine (1992), Pravilnik o postupku, načinu i uvjetima ocjenjivanja i napredovanja nastavnika srednjih škola, 86/1992 (12. 12. 1992.).

[NN] Narodne novine (1995), Pravilnik o napredovanju učitelja i nastavnika u osnovnom i srednjem školstvu, 86/1995 (25. 10. 1995.).

[NN] Narodne novine (2003), Pravilnik o polaganju stručnog ispita učitelja $i$ stručnih suradnika u osnovnom školstvu i nastavnika u srednjem školstvu, 88/2003 (28. 5. 2003.).

[NN] Narodne novine (2008), Državni pedagoški standard osnovnoškolskog sustava odgoja i obrazovanja, 63/2008 (2. 6. 2008.).

[NN] Narodne novine (2008), Zakon o odgoju i obrazovanju u osnovnoj i srednjoj školi, 87/2008 (2. 6. 2008.).

[NN] Narodne novine (2018), Zakon o odgoju i obrazovanju u osnovnoj i srednjoj školi, 68/2018 (27. 7. 2018.).

OECD (2014), Talis 2013 results: An international perspective on teaching and learning, Paris: OECD Publishing.

doi: https://doi.org/10.1787/9789264196261-en

Paechter, Carrie (1996), »What do we mean by professional development?«, Research in Post-Compulsory Education, 1(3), str. 345-355.

doi: https://doi.org/10.1080/1359674960010305

Pažin-Ilakovac, Ružica i Skelac, Mirela (2010), »Stručno usavršavanje u organizaciji Agencije za odgoj i obrazovanje - opis stanja«, u: Milović, Sanja (ur.), Stručno usavršavanje i profesionalni razvoj: Zbornik radova, Zagreb: Agencija za odgoj i obrazovanje, str. 11-14.

Poljak, Vladimir (1988), Povijesna analiza unutarnje reforme osnovne škole, Zagreb: Institut za pedagogijska istraživanja, Filozofski fakultet Zagreb.

Potkonjak, Nikola (1981), Izabrana dela III, Osijek: Sveučilište u Osijeku, Pedagoški fakultet.

Potkonjak, Nikola i Šimleša, Pero (ur.) (1989), Pedagoška enciklopedija 2, Beograd: Zavod za udžbenike i nastavna sredstva.

Puljiz, Vlado (2008), »Socijalna politika Hrvatske«, u: Puljiz, Vlado et al. (ur.), Socijalna politika Hrvatske, Zagreb: Pravni fakultet Sveučilišta u Zagrebu. 
Rich, Edna A. (1905), Paper Sloyd: priručnik za osnovne razrede, Boston: Ginn \& Company.

Sahlberg, Pasi (2012), Lekcije iz Finske, Zagreb: Školska knjiga.

Službeni glasnik pokrajinske uprave za Hrvatsku i Slavoniju, odjeljenja za prosvjetu i vjere (1992), Naredba Pokrajinske uprave za Hrvatsku i Slavoniju od 20. 5. 1922., br. 20.588 kojom se u ljetnim praznicima godine 1922. uređuje u kr. višoj pedagoškoj školi u Zagrebu tečaj za stručno usavršavanje učitelja šegrtskih škola, IX/1922.

Vizek Vidović, Vlasta (2005), Cjeloživotno obrazovanje učitelja i nastavnika: Višestruke perspektive, Zagreb: Institut za društvena istraživanja u Zagrebu.

Vrgoč, Hrvoje (2007), Naših sto trideset pet godina, Zagreb: HPKZ.

\section{HISTORICAL DISCOURSE OF PROFESSIONAL DEVELOPMENT AND CONTINUING TEACHER TRAINING}

\section{Mirko Lukaš}

By comparative analysis of selected historical and contemporary pedagogical documents, professional development is recognized as a permanent and inseparable component of the teaching profession. Continuous training of educators is unfairly attributed only to the time of the lifelong education paradigm. Since its beginnings and attempts at legislation and its social establishment, pedagogical theorists have prescribed the continuing need for professional development for the purpose of professional development and career advancement, as well as the obligation of continuous learning. Already in the first legal document of 1874, individual and extended education of all teachers was prescribed. In this way, professional development becomes a key component of the teaching profession and later of all educational staff. The analysis of historical documents has determined the one hundred and fifty-year legal and statutory regulation of a permanent obligation for the professional development of teachers, which is often not achieved in practice. After reaching the university level of initial education of all teachers, it is necessary to create the conditions for their systematic and effective professional development.

Key words: lifelong education, vocational learning, continuing education, school regulations 